\title{
Contested sovereignties: The case of the "New World Information and Communication Order" at UNESCO in the 1970s
}

\begin{abstract}
Intense debate on the reform of international relations and greater global justice marked the 1970s. Global economic reform was hotly discussed at the UN and elsewhere under the label of a "New International Economic Order". A similar initiative emerged at the UN's cultural organisation UNESCO, proposing a "New World Information and Communication Order". This article argues that, early in the 1970s, representatives of the Non-Aligned Movement and the leadership of UNESCO promoted the inclusion of culture into the pursuit of a new international order, focusing above all on global media practices. The debate about a 'New World Information and Communication Order' (NWICO) produced far reaching claims about the impact of media on (national) culture(s), their role in national development and international politics. Notions of sovereignty stood at the heart of this debate. While UNESCO claimed a central role in defining culture's place in international relations and offered newly independent states an arena for sovereign performances in international politics, the debate itself was essentially about probing the limits of state sovereignty with a view to media and communication.
\end{abstract}

\section{Introduction}

A UNESCO report in 1976 stated that the 1970 s will be remembered as the "communication decade". Optical fibers, satellite communication, colour TV, and many more recent technological advances had led to an "explosion" of communication possibilities, the report stated. Simultaneously, a "rethinking” took place around the world that understood communication less in functional terms than as a pervasive factor within the socio-economic fabric of society. ${ }^{1}$ Communication scientists

1 John Lee, Towards Realistic Communication Policies. Recent Trends and Ideas Compiled and Analysed, Paris 1976, available at: UNESCO Digital Library (UNESDOC), URL: https://unesdoc. unesco.org/ (2020-01-31).

Ә Open Access. () 2021 Jonas Brendebach, published by De Gruyter. (c) BY-NC-ND This work is licensed under the Creative Commons Attribution-NonCommercial-NoDerivatives 4.0 International License. https://doi.org/10.1515/9783110679151-006 
saw a new communication revolution rising, sociologists debated concepts like knowledge industries and the information society.

For some time, proponents of international history have grappled with the transformations of the 1970s. Earlier forays emphasised the crisis character of this era and the perceived loss of control of the United States and its Western allies over the post-war international order. ${ }^{2}$ More recent literature has turned towards the reform efforts hotly discussed throughout the international system at the time. Especially non-aligned and developing countries, many of which had only recently attained independence and statehood, used the United Nations and other international fora to criticize structural imbalances in global political and economic relations. The Cold War purview came to share with decolonization and a North-South divide as determining contexts for international politics. ${ }^{3}$

More specifically, historians have reappraised the significance of the "New International Economic Order" (NIEO), a project to reform the global economy promoted by countries of the Global South at the meetings of the Non-aligned Movement, at the UN, UNCTAD and elsewhere. ${ }^{4}$ Yet, this reappraisal remains incomplete if we do not take into account a parallel project pursued by a similar set of actors and discussed predominantly at the UN's cultural organization, UNESCO: The "New World Information and Communication Order" (NWICO). ${ }^{5}$

While the "C" in UNESCO stands for culture, communication was on the organisation's agenda from the beginning. By its constitution it was tasked to advance international understanding "through all means of mass communication" and to promote "the free flow of ideas by word and image". ${ }^{6}$ People who knew about each other, the basic idea went, were developing ties and were less likely to go to war. During the 1960s, UNESCO drew on the collaboration with North

2 Niall Ferguson et al. (eds.), The Shock of the Global: The 1970s in Perspective, Cambridge/ MA. 2010.

3 Glenda Sluga, Internationalism in the Age of Nationalism, Philadelphia 2013, 118-149.

4 Nils Gilman, 'Toward a History of the New International Economic Order', in: Humanity 6/1 (2015), 1-16; Samuel Moyn, Not Enough. Human Rights in an Unequal World, Cambridge 2018, 113-118.

5 The NWICO still presents a gap in international histories, as an exception see Vanessa Freije, 'The "emancipation of media": Latin American advocacy for a New International Information Order in the 1970s', in: Journal of Global History 14/2 (2019), 301-320. The broader genesis of the NWICO and UNESCO's approach in organizing this debate were subjects of my dissertation: A New Global Media Order? Debates and Policies on the Media and Mass Communication at UNESCO - 1960 to 1980, PhD Manuscript, Florence 2019. For a concise overview see Ulla Carlsson, 'The Rise and Fall of NWICO. From a Vision of International Regulation to a Reality of Multilevel Governance', in: Nordicom Review 24/2 (2003), 31-67.

6 'Constitution', in: UNESCO, Basic Texts, Paris 2010, UNESDOC. 
American social scientists to define ways in which mass communication could enhance national development in the Third World. ${ }^{7}$ But at the latest with the advent of satellites and the prospect of limitless flows of media and information across borders, it dawned upon cultural and development planners at UNESCO that the new media could starkly increase the already existing asymmetries in global information flows and have antagonizing effects.

The following essay argues that both representatives of the Non-Aligned Movement and the leadership of UNESCO early on in the 1970s promoted the inclusion of media and mass communication, often packaged as cultural component, into the pursuit of a new international order. While contemporaries, including UNESCO experts, avoided defining culture and instead applied the notion in the broadest sense, they did formulate a concrete policy agenda addressing what we may call global media practices. It made far reaching claims about the impact of media on (national) culture(s), their role in national development and in the (un)making of international order.

At the core of a new media order stood notions of "sovereignty" and "selfreliance" in the communication field and the "decolonization of information". "Cultural self-determination" and the protection of "cultural identity" were linked with "national sovereignty". The phrase "cultural sovereignty" gained currency in the contemporary debate. All these terms shared a strong emphasis on the national and the nation state as basic category for policy formulation. They also made a strong claim about the importance of culture in the process of becoming, establishing and protecting a nation state. The NWICO label lumped together a host of notions and claims related to culture and mass media and sought to make them debatable and governable.

Moreover, advocates of a new media order held that global reform in international cultural relations was just as necessary as in international economic relations to achieve greater social justice among nations. The second main argument of this essay then poses that if economic sovereignty stood at the center of the NIEO debate, enabling and protecting sovereignty in the cultural field formed the core of the NWICO. It even came to be seen as necessary pre-condition for the realization of international economic reform. Yet claims to informational sovereignty made at the international level often encountered challenges and tensions, as will be seen, at the level of international horizontal cooperation and of national practice.

UNESCO's leadership early on aligned its own institutional interests with the political agenda advanced by the non-aligned countries. UNESCO's Mass

7 Wilbur L. Schramm, Mass Media and National Development: The Role of Information in the Developing Countries, Stanford 1964. 
Communication Department played a central role in promoting research into the intricacies of international communication. The resulting body of literature provided argumentative fodder for the policy debates. Non-aligned countries, in turn, sought UNESCO support in practically expanding their communication capacities and promoted regulatory and normative measures at UNESCO meetings and conferences. UNESCO became a nodal point of the debate and its single most important international forum.

\section{The NIEO-moment and the momentum of culture}

The initiative for a "New International Economic Order" arrived at a moment of discontent as much as of opportunity. The discontent on part of the Third World grew mostly from the realization that the attainment of independence and subsequent international efforts in development, notably the First United Nations Development Decade in the 1960s, had raised expectations but not delivered economic growth and social progress. Instead, a sense of economic exploitation - often branded as neo-colonialism - spread across the Global South. Opportunity arose when Cold War tensions receded under the sign of Great Power détente in the early 1970s. Attention shifted to a new polarization - that between North and South. By 1973, the United Nations counted 135 sovereign member states, a vast majority called itself self-consciously "Third World" or "developing countries". The same year the oil embargo of the Organisation of Petroleum Exporting Countries (OPEC), beginning in October 1973, and the following shock to mainly, if not only, Western economies, served as sign of inspiration. If the non-industrialised countries joined forces and controlled their raw materials, they could wield considerable power over the North.

The NIEO initiative took shape when the Non-Aligned Movement gathered for its Fourth Summit in Algiers in September 1973. Algerian President Houari Boumédiène led the group to draw up a programme for international reform. Only a few months later, the UN General Assembly adopted the Declaration on the Establishment of a New International Economic Order and a Programme of Action at its Sixth Special Session. Both were supported by the majority of nonaligned and developing countries.

Rather than presenting a single coherent project, historian Nils Gilman has argued, the NIEO represented a "political brand" encompassing economic, legal, and political measures aiming at "reforming global economic and political power 
arrangements". ${ }^{8}$ Politically, the NIEO Declaration spoke a language of national sovereignty, self-determination and development. It claimed "the right of every country to adopt the economic and social system that it deems the most appropriate for its own development”. In economic terms, the Declaration spoke a language of nationalization and redistribution. It insisted on the "full permanent sovereignty of every State over its natural resources and all economic activities" and urged stronger regulation of transnational corporations. ${ }^{9}$ It described the NIEO process as a concerted effort of the entire international community and requested all UN members as much as other UN branches to contribute.

Reference to culture did neither occur in the Declaration nor in the Programme for Action, a fact that was quickly picked up at UNESCO in Paris. Its French Director-General, René Maheu, warned the UN Economic and Social Council in July 1974 that the "expression 'new international economic order' should not be taken literally, otherwise we might be seriously misled as to the scope and nature of what is being undertaken." From UNESCO's point of view, he argued that the "main omission in the Declaration pertains to the socio-cultural dimension of development." He contextualised the "socio-cultural dimension" in contemporary development thinking and advocated adding a cultural component as indispensable corollary to the economic dimensions of a new international order and an important element for greater international justice. ${ }^{10}$

Since his election in 1962, Maheu had spent much effort on having social and cultural aspects recognised as inherent elements of development policies. ${ }^{11}$ He counted among the gains of the First Development Decade the realization that development measured by GDP growth alone was not enough to bring about social progress. To him the "social aspect" pertained to a wide array of political conditions ranging from social services and health care to education and cultural activities. Remaining vague on the concept of culture, Maheu pointed to

8 Nils Gilman, 'The New International Economic Order. A Reintroduction', in: Humanity 6/1 (2015), 1-16, here 2.

93201 (S-VI) Declaration on the Establishment of a New International Economic Order and 3202 (S-VI) Programme of Action on the Establishment of a New International Economic Order, available on: United Nations Official Document System (UN ODS), URL: https://documents.un. org/prod/ods.nsf/home.xsp (2020-01-31).

10 UNESCO, Records of the General Conference, 18th Session, Paris 1974, 18 C/103, Ways and Means Whereby UNESCO Could Contribute to the Establishment of a New International Economic Order, and Annex I, Extracts from the Address given by the Director-General to the FiftySeventh Session of the United Nations Economic and Social Council (Geneva, 5 July 1974), Paris, 01.10.1974.

11 On this period: Chloé Maurel, Histoire de l'UNESCO. Les trente premières années 1945-1974, Paris 2010, 269-276. 
categories like "dignity", "happiness" and "values which make life worth living" and of which "culture is both the custodian and critic". ${ }^{12}$ Turning to the present task of reforming the international order, Maheu declared that greater international justice, as intended by the NIEO proponents, meant that not only the powerful and rich states were able to speak up and protect their conditions of living but all states: "National economic independence, following on from political independence, must go hand in hand with a corresponding emancipation of the people." That would be the "definition of social progress". ${ }^{13}$

Some groundwork had already been laid at UNESCO. In 1966, member states had adopted a Declaration on the Principles of International Cultural Cooperation stating that "each culture has a dignity and value which must be respected and preserved" and "every people has the right and duty to develop its culture". Only a few months later the UN General Assembly adopted the International Covenant on Economic, Social and Cultural Rights declaring that by virtue of the right of self-determination, all peoples had the right "to freely pursue their economic, social and cultural development". ${ }^{14}$

By inscribing UNESCO's fields of competence in the international reform effort, Maheu effectively aligned its institutional interests with the momentum surrounding the non-aligned countries and the NIEO. UNESCO was ideally situated to offer guidance in how to spell out the "socio-cultural factors" in the broader reform plans. At a moment at which the UN system itself was subject to intense reform debate, ${ }^{15}$ Maheu made the case for the relevance of UNESCO's work as much as for its claims to be funded accordingly. When Maheu, by the end of 1974, passed the baton to a new Director-General he left a policy agenda ready to pick up by the new leadership.

Despite the omission in the NIEO Declaration and Programme, the nonaligned countries were deeply aware of the role cultural relations played in the (un-)making of international order. At the Algiers Summit in 1973, the heads of state and government had openly attacked what they described as "imperialism" in the cultural field. Their diagnosis held that "the activities of imperialism are not confined solely to political and economic fields but also cover the cultural and social fields, thus imposing an alien ideological domination over the

$1218 \mathrm{C} / 103$, Annex I.

13 Ibid.

14 UNESCO, Records of the General Conference, $14^{\text {th }}$ Session, Paris 1966, 14 C/Resolutions, Declaration of Principles for International Cultural Co-operation [Resolution 8.1], UNESDOC, 86-89. 15 The decade had begun with a much-discussed critical review of the UN system: A Study of the Capacity of the United Nations Development System [Jackson-Report], DP/5, 2 vols., Geneva 1969, UN ODS. 
peoples of the developing world." They criticised the "cultural alienation and the imported civilization imposed by imperialism" and stressed the need to "reassert indigenous cultural identity" and to preserve "national culture and traditions". ${ }^{16}$ "Cultural imperialism" - a term mainly used in academic contexts before - became henceforth a contested concept in international politics. ${ }^{17}$

Going beyond the abstract level of a cultural critique, non-aligned countries called for collective action in the communication field and greater exchange on the horizontal level. Concrete proposals included the "collective ownership of [a] communication satellite", a review of multilateral cable rates and exchange programmes to ensure that people, knowledge and ideas could travel within the developing world. Newspapers, radio and television were supposed to disseminate "information concerning [the non-aligned countries'] mutual achievements in all fields". ${ }^{18}$ In the following years, the non-aligned countries intensified their cooperation on information and communication and established a permanent coordinating committee. A major Symposium on Information was held in Tunis in March 1976 to address conceptual and political questions in this field. It was there that the phrase "new international information order" first appeared. ${ }^{19}$ Meanwhile, to address the practical side of the problem, the Yugoslav national news agency Tanjug started a network of cooperations among news agencies across the Non-Aligned Movement which led to the constitution of the Non-Aligned News Agencies Pool (NANAP) in 1976.

UNESCO not only closely watched the activities of the non-aligned countries but actively participated and steered its own programme in a corresponding direction. For the non-aligned, the resources, communication channels, and arguments provided by UNESCO facilitated the formulation of a political agenda and amplified their calls for reform. UNESCO also offered a specific repertoire

16 UN General Assembly, Documents of the Fourth Conference of Heads of State or Government of Non-Aligned Countries, held at Algiers, from 5 to 9 September 1973, A/9330, 22.11.1973, 73-74, UN ODS. On the Algiers Summit see Jürgen Dinkel, Die Bewegung Bündnisfreier Staaten: Genese, Organisation und Politik (1927-1992), Berlin 2015, 149ff.

17 An early articulation: Herbert I. Schiller, Mass Communications and American Empire, New York 1969.

18 UN GA, Documents of the Fourth Conference [of Non-Aligned Countries], UN ODS, 88-89.

19 First Symposium of Non-Aligned Countries on Information, a. Final Report, b. Report of the First Committee: The Emancipation of Mass Media in the Non-Aligned Countries, c. Report of the Second Committee: The Role of Information in the Development of Economic and Social Co-operation Among Non-Aligned Countries, d. Report of the Third Committee: The Role of Information in the Development of Cultural Interaction Among Non-Aligned Countries, in: Odette Jankowitsch and Karl P. Sauvant (eds.), The Third World Without Superpowers: The Collected Documents of the Non-Aligned Countries, vol. IV, Dobbs Ferry 1978, 1931-1963, here 1953. 
for action, ranging from expert advice, supply of scientific knowledge and coordination to normative action as far as member states at its General Conference could agree on.

\section{Towards a new global media order}

\section{The diagnosis}

The close alignment between UNESCO and the Non-Aligned Movement was not coincidental. It was a logical consequence of UNESCO's recent turn in its engagement with communication and information. Around 1970, the research commissioned by UNESCO's Mass Communication Department took a critical distance from the USdominated approaches followed in the 1950s and 1960s. A new cohort of mainly European communication researchers, notably from Western and Eastern Europe, questioned the assumption that the mere growth of mass media and the "free flow of information" in developing societies would shepherd them along a projected path to modernization. They pointed to the ideological underpinnings of such a model and stressed the tensions arising when foreign socio-cultural products encountered societies in the Global South without due consideration of their own socio-cultural characteristics and exigencies, including political ambitions. ${ }^{20} \mathrm{An}$ important element of this new research was the analysis of global disparities in the production of media content. A landmark study conducted by the Finnish media scholars Kaarle Nordenstreng and Tapio Varis analysed TV programmes in 50 countries. Their data showed the overwhelming dominance of the United States, the United Kingdom, France and West Germany in the global export of TV programmes. Surveys in Latin America and the Asian-Pacific evidenced that developing countries remained on the receiving end. ${ }^{21}$

20 James D. Halloran, Mass Media in Society: The Need of Research, Paris 1970, UNESDOC. For an iconic cultural critique outside UNESCO see Ariel Dorfman and Armand Mattelart, How to Read Donald Duck: Imperialist Ideology in the Disney Comic, New York 1975 [Orig. in Spanish in 1971].

21 Kaarle Nordenstreng and Tapio Varis, Television Traffic - A One-Way Street? A Survey and Analysis of the International Flow of Television Programme Material, Paris 1974, UNESDOC. See also the Report of the International Commission for the Study of Communication Problems (ICCP), Many Voices, One World: Communication and Society Today and Tomorrow. Towards a New More Just and More Efficient World information and Communication Order (also known as MacBride-Report), London 1980, UNESDOC, esp. chapters Disparities, 123-134, and Flaws in Communication Flows, 137-155. 
Another issue pertained to the availability of news and was intrinsically linked to the historical origins of the existing infrastructure for international communication. The latter had developed in form of telegraph and telephone lines to no small degree in the era of colonialism. ${ }^{22}$ The result was a communication grid that favored a "vertical" flow of communication from Europe to the colonies, rather than a "horizontal" exchange of information among neighbouring societies outside of Europe. Since the middle of the nineteenth century, the British news agency Reuters and the French Agence France Press acquired dominance on the global news market. By the early twentieth century, they were rivaled by the American Associated Press, United Press International and, after the Second World War, also by the Soviet TASS. ${ }^{23}$ The result was that African countries, for example, experienced a dearth of information on developments in their own regions since they depended on news dispatches from the "Big Four/Five" who geared their news production towards the needs of societies in the Northern hemisphere. A vertically organised communication grid and the market dominance of the big agencies hindered the establishment of alternative news agencies that could cater to the needs of developing regions.

A third concern related to the image of the developing countries that was transmitted internationally. Studies held that international press reporting on these countries was dominated by a focus on all forms of crisis, political, economic or natural. In the absence of adequate means to influence the representation of their country in foreign media, governments found it difficult to attract foreign investment or public interest. This also reflected on the self-perception of the countries, both politically and culturally, and on the public perception of their respective national governments. ${ }^{24}$ The empirical evidence provided by

22 Daniel T. Headrick, The Invisible Weapon: Telecommunications and International Politics 1851-1945, Oxford 1991; Roland Wenzlhuemer (ed.), 'Global Communication: Telecommunication and Global Flows of Information in the late 19th and early 20th century', Special Issue of Historical Social Research 31 (2010). For a contemporary critique see esp. the papers of two main NWICO proponents Bogdan Osolnik, Aims and Approaches to a New International Communication Order, Paris 1978; Mustapha Masmoudi, The New World Information Order, Paris 1978, UNESDOC.

23 Volker Barth, Wa(h)re Fakten. Wissensproduktionen globaler Nachrichtenagenturen 1835-1939, Göttingen 2019.

24 Most comprehensively: Annabelle Sreberny-Mohammadi et al., Foreign News in the Media: International Reporting in 29 Countries, Paris 1985, UNESDOC. Already in the late 1970s several studies in the context of the so-called MacBride-Commission were concerned with image projection through the media. It is more than a coincidence that around the same time the seminal work Orientalism of literary scholar Edward Said appeared, tackling a similar questions on 
the numerous UNESCO studies was used to challenge the present state of global communications. In turn, the growing number of international conferences, expert meetings and working groups at UNESCO as well as within the Non-aligned Movement provided arenas where these arguments could be rehearsed and exchanged. Together, they provided indispensable momentum for the claim to establish a new media order.

The debate received a recognizable label, when in 1976 the already mentioned symposium on information took place in Tunis. A report of this ministerial meeting spoke of "a new international order in information", coining a phrase that immediately went into common use. Actors who wanted to stress the analogy to the NIEO preferred the acronym NIIO. At UNESCO, the phrase "New World Information and Communication Order" (NWICO) became established and later on the more frequently used term. The NIIO/NWICO-label turned into a shorthand for a series of cultural grievances concerning the identity, representation and voice of Third World countries on the global stage and, most importantly, rendered them operable in a concrete policy field - that of mass media and communication.

\section{How to "decolonize information"}

The most immediate measure of the non-aligned countries was to set-up a cooperative mechanism among national news agencies across the Non-Aligned Movement. Following the Algiers summit of 1973, the Yugoslav TANJUG had prepared cooperation among 16 non-aligned news agencies. In July 1976 in New Delhi, non-aligned information ministers institutionalized this cooperation by setting up a "Non-Aligned News Agencies Pool". ${ }^{25}$ Indian Prime Minister Indira Gandhi herself greeted the ministers from some sixty countries:

In spite of our political sovereignty, most of us who have emerged from a colonial and semi-colonial past continue to have a rather unequal cultural and economic relationship with our respective former overlords. Even our image of ourselves, not to speak of the

how the West's perception of the other, especially of the developing world, turned into a relationship of unequal power distribution. See Edward W. Said, Orientalism, London 1978.

25 A contemporary account of the NANAP: Pero Ivacic, 'The Flow of News. Tanjug, the Pool, and the National Agencies', in: Journal of Communication 28/4 (1978), 157-162. For a historical perspective on the agency see Jürgen Dinkel, 'Dekolonisierung und Weltnachrichtenordnung. Der Nachrichtenpool bündnisfreier Staaten (1976-1992)', in: Frank Bösch and Peter Hoeres (eds.), Außenpolitik im Medienzeitalter: Vom späten 19. Jahrhundert bis zur Gegenwart, Göttingen 2013, 211-231. 
view of other countries, tends to conform to theirs. [. . .] We want to hear Africans on Africa. You should similarly be able to get an Indian explanation of events in India. ${ }^{26}$

The Conference spelled out Gandhi's implicit criticism by noting "serious inadequacy and imbalance" in global information flows and stating that a "great majority of countries are reduced to being passive recipients of information". "Cultural dependence" ultimately delayed "the achievement of political and economic growth". The conference called for a "decolonization of information". ${ }^{27}$

The establishment of the NANAP was meant to solve several problems. Its goal was the provision of "objective information" with an "emphasis on progressive, economic, socio-cultural and cultural developments as well as mutual cooperation and action". It aimed at facilitating the dissemination of such information "among non-aligned countries as well as the international community in general" thus filling an alleged gap in international news. The Pool was explicitly not designed as "supra-national news agency" but as cooperation among national news agencies based on "full respect for equality and democratic principles". The participating countries maintained full control of the information they wished to distribute within their national borders. ${ }^{28}$

UNESCO had long promoted regional news cooperation. As early as 1961 and 1963, two expert meetings held in Bangkok and in Tunis addressed the question of setting up national and regional news exchanges in Asia and Africa respectively. ${ }^{29}$ Despite concrete proposals and tentative projects, however, it was not until the late 1970s that regional news agencies in the Caribbean (CANA 1976), Latin America (ALASEI 1979), and Africa (PANA 1979) proliferated. $^{30}$ For the time being, the NANAP remained the most ambitious and concrete project that addressed the NIIO/ NWICO-concerns. UNESCO's nineteenth General Conference, held in Nairobi in autumn 1976, decided to make UNESCO resources directly available to the project. ${ }^{31}$

26 After Roger Tatarian, 'News Flow in the Third World. An Overview', in: Philip Horton (ed.), The Third World and Press Freedom, New York 1978, 1-54, here 26.

27 Specialised Ministerial Conference of Non-Aligned Countries: Ministerial Conference on the Press Agencies Pool, New Delhi, July 8-13, 1976, in: Jankowitsch/ Sauvant (eds.), Third World Without Superpowers, vol. III, 1553-1580, here 1554-1557.

28 See Draft Constitution in: ibid, 1562-1570.

29 UNESCO, Report of the Meeting of Experts on Development of News Agencies in Asia and the Far East, Bangkok, December 19-23, 1961, UNESCO/MC/44, and: UNESCO, Report of the Meeting of Experts on the Development of News Agencies in Africa, Tunis, April 1-6, 1963, UNESCO/ $\mathrm{MC} / 48$, both UNESDOC.

30 'UNESCO and News Agency Development', in: UNESCO Courier 30/4 (1977), UNESDOC, 6. 31 UNESCO, Records of the General Conference, $19^{\text {th }}$ Session, Nairobi 1976, 19 C/5 Programme and Budget, Project Promotion of free and balanced flow of information and of international exchange, UNESDOC, para. 4158. 
UNESCO observers were regular participants in the Coordinating Committee of NANAP and in internal memos they drew up further options of support. ${ }^{32}$

Indeed, the first ten years of the Pool have been described as a success story. From the beginning in January 1975, the number of participating news agencies had grown to 30 until summer $1976 .{ }^{33}$ Ministers from around 60 non-aligned countries travelled to the conference in New Delhi the same year. By 1977, 14 countries volunteered to serve as regional distribution centers. The news output of the Pool reached some 40.000 words per day in 1979, which was, however, still marginal compared to AP or Reuters who turned over one million words per day. In the early 1980s, the NANAP also secured an agreement with the United Nations Office for Public Information to have its dispatches distributed alongside the news items from the major Western and Soviet news agencies.

However, as historian Jürgen Dinkel demonstrated, despite the broad agreement about the need for such a Pool - even Western media commented favorably - its actual public impact was little and declined rapidly. ${ }^{34}$ The reasons ranged from poor equipment, the lack of consistency in journalistic standards, to questions of credibility as well as usefulness, when information was delayed or contradictory. The expectation of a distinct political function of the news coming from NANAP and the insistence of governments to maintain control prevented effective reform and led the NANAP into increasing irrelevance as "alternative" news agency by the 1980s. ${ }^{35}$ At the heart of this troubled history of regional cooperation stood, among other things, a problem of national sovereignty. Esmond Wickremasinghe, chairman of the Sri Lanka Newspaper Association, unpacked the conundrum at a UNESCO expert meeting in 1977. As governments remained the ultimate decision makers about what news was distributed, multilateral news exchange should focus on areas where common interest and widespread agreement existed. For example, in the case of the Third World's fight against poverty news agencies should report the "experiences of different states, their policies,

32 Hifzi Topuz, Les relations de l'UNESCO avec les organismes de communication du mouvement des pays non-alignes, 16.3.1978, in: AG 8, Central Registry Collection (CRC) 1967-1989, Folder: COM DCS 04929 I NANAP, UNESCO Archives, Paris (UAP).

33 The following numbers are based on Dinkel, 'Dekolonisierung und Weltnachrichtenordnung', 217-219.

34 Ibid., 223-228.

35 The creation of alternative news agencies was not the only strategy to tackle the problem of news supply: James Brennan has shown how East African states sought to place international agencies under some control through means of negotiation and diplomacy. Reuters, in order to maintain its market position, adapted its product to respond better to regional needs. See James R. Brennan, 'The Cold War Battle over Global News in East Africa: Decolonization, the Free Flow of Information, and the Media Business, 1960-1980', in: Journal of Global History 10/2 (2015), 333-356. 
their failures and their successes". ${ }^{36}$ But this was missing the political reality. Despite shared challenges, Third World countries were also competing for authority, influence and prestige among each other as well as, often enough, for public acceptance domestically. As a consequence, reporting on national failures was unlikely and the texts were fraught with officialdom.

Worse still, as Wickremasinghe pointed out, many agencies and media outlets in the developing world depended on public funding. Under politically volatile circumstances, this could not but affect editorial decisions which further undermined the news value of the disseminated texts. Clearly, greater independence from foreign markets and national sovereignty in the field mass media resulted in a scramble for control by national governments. The decolonization of information in many cases led to the substitution of foreign control by domestic governmental control that equally did not help an independent media to grow in the developing world.

\section{The technological challenge}

In the meantime, the arrival of satellite broadcasting had lent additional immediacy to the problem of national sovereignty in the communication field. Initially interested in its potential for educational uses in remote developing areas, experts at UNESCO soon began work on international legal guidance in order to address the inherent transnational quality of satellites. In 1972, UNESCO's General Conference adopted a Declaration of Guiding Principles on the Use of Satellite Broadcasting. The Declaration attempted to reconcile the potential expansion of cultural exchange with the protection of cultural identities. It stated that satellite communication had to "respect the sovereignty and equality of all States". Cultural programs had to "respect the distinctive character [. . .] of each, and the right of all countries and peoples to preserve their cultures as part of the common heritage of mankind". It called upon states to reach "prior agreements" before broadcasting via satellite into foreign countries. ${ }^{37}$

36 Esmod Wickremasinghe, The Quest for Third World News Agencies, Asian, African or Latin American, UNESCO Meeting of Experts on the Development of News Agencies in Asia, Colombo, 5-9 December 1977, UNESDOC.

37 UNESCO, Records of the General Conference, $17^{\text {th }}$ Session, Paris, 1972, 17 C/Resolutions: Declaration of Guiding Principles on the Use of Satellite Broadcasting for the Free Flow of Information, the Spread of Education and Greater Cultural Exchange, 15 November 1972, UNESDOC. 
This so-called "prior-consent clause" was intended to safeguard cultural diversity in the sense of UNESCO's 1966 Declaration on Cultural Co-Operation. But the United States, the technological leader in the field, along with the Western Europeans rejected the governmental prerogative to decide which media content could cross national borders that the Declaration implied. This would hamper press freedom and run against a core idea of Western liberal democracy. While the Western states voted against the Declaration or abstained, a majority of developing and socialist countries secured its adoption. The text had no binding legal power, and in the absence of an actual consensus it also lacked normative authority.

The controversy had shed light on the conflictual relation between technological progress in communication media, the ambition to preserve distinct cultures and the claim to national sovereignty. Soon another declaration project, already under way at UNESCO, would further spell out this conflict. It had its origins in a proposal advanced by socialist countries in 1970 and was born out of the desire to extend such normative instruments to address international communications generally. UNESCO embarked on a journey to draft a declaration on guiding principles for the mass media. ${ }^{38}$

\section{Contested sovereignty over culture}

This declaration project started clearly before the non-aligned initiative for an NIEO took shape. Yet, when the NIEO debate arrived, it afforded UNESCO with the opportunity to frame its concern with the global flow of information within a framework of global reform. By packaging its own "brand" of a reformed world order centering around communication practices and notions of cultural sovereignty, UNESCO took the chance of claiming center stage itself within the controversial North-South-debates that marked international politics during the 1970s and early 1980s.

From the first calls in 1970 to its final adoption in 1978, a broad array of topics was up for discussion and possible inclusion into the Mass Media Declaration. They

38 For the sake of simplicity, I will speak of the Mass Media Declaration. Its full title was subject to continued controversy and revision. Its final version read: UNESCO, Records of the General Conference, $20^{\text {th }}$ Session, Paris 1978, 20 C/20 Rev., Declaration on Fundamental Principles Concerning the Contribution of the Mass Media to Strengthening Peace and International Understanding, to the Promotion of Human Rights and to Countering Racialism, Apartheid and Incitement to War, 21.11.1978, UNESDOC. 
ranged from diagnostic statements on the under-representation of the Third World to normative claims on the role of the media in fighting racism, discrimination and neo-colonialism, from cultural functions like the protection of cultural diversity to the role of the state in building national media and exercising oversight over content, from the media's role in international relations to preferential treatment of the Third World on the international communication systems. ${ }^{39}$ The lines of conflict were multiple and ran between East and West, market-oriented press freedom advocates and critical left-leaning communication scholars, socialist journalists and North American media associations, defenders of state action and promoters of a self-regulatory approach, etc. Conflicts ran across states, political camps and geographies and made for a truly global debate.

Within this broad debate, representatives from the non-aligned countries formed arguably the most dynamic, if heterogeneous, group of actors, whose emerging position is traced here. I will focus on claims for sovereignty in the communication field in the three distinct, yet interconnected, dimensions of the economic, the cultural and the political.

This has to start though with a look at a prominent individual who had taken over the leadership of UNESCO from René Maheu: The Senegalese Amadou Mahtar M'Bow, elected Director-General in 1974. The 53-year former school teacher, education minister and international civil servant had received the votes from all ideological camps and geographic regions represented at UNESCO. Being the first person of color to head a UN organization, he considered his mandate as nothing less than to contribute to "set[ting] international co-operation on an increasingly equitable footing". 40

Once in office, he quickly showed himself an ardent supporter of the New International Economic Order. Picking up from Maheu's critical appraisal of the NIEO, M'Bow was quick to embed the economic program into a broad campaign for a "new and more equitable world order" in which communication and information were to play an integral part. ${ }^{41}$ When in 1976, UNESCO’s General Conference convened for the first time on African soil, in Nairobi, Kenya, M'Bow's speeches were replete with references

39 On the Mass Media Declaration: UNESCO, Historical Background of the Mass Media Declaration, Paris 1982, UNESDOC, and Kaarle Nordenstreng and Lauri Hannikainen, The Mass Media Declaration of UNESCO, Norwood 1984.

40 After Fernando Valderrama, A History of UNESCO, UNESCO 1995, UNESDOC, 223. As one of the most important representatives of the Third World on the international stage after 1945, M'Bow has not yet received broader attention. For a profile see Pierre Kalfon, 'Amadou Mahtar M'Bow', in: UNESCO Courier 28/2 (1975), UNESDOC, 14-18.

41 Amadou-Mahtar M'Bow, Moving Towards Change: Some Thoughts on the New International Economic Order, Paris 1976, UNESDOC, 9. 
to the NIEO and a "new international/world order". He directly linked this to a "new order in communication" and a "new cultural order", terms that other delegates had used before him. ${ }^{42}$ M'Bow was evidently encouraging those who wished UNESCO to declare the equivalent of an NIEO in the media and communications field. Even more than Maheu, M'Bow was set to make UNESCO a focal point for global reform.

Meanwhile the non-aligned countries further spelled out their concept of a new media order at the Symposium in Tunis. The economic dimension of the non-aligned claims departed from the assumption that information was not a commodity but a social good in the service of the development of the people. ${ }^{43}$ In practical terms it referred to both the ownership of the major media operating in a state and the international market conditions which seemed to impede the development of national media in developing countries. The Tunis deliberations stressed the "negative role" played by the "big press transnationals" (to read AP, UPI, Reuters, AFP, TASS) and called for a "decolonization of information". In similar terms, M'Bow had criticised the de-facto monopoly of the dominant, mostly Western news agencies ("a few transnational companies"). The international community would need to "endeavour to restructure the international telecommunication system". ${ }^{44}$ To remedy the situation, non-aligned actors floated at UNESCO meetings in 1975 and 1976 ideas such as "the transfer of the ownership of the mass media to the social sectors and for international governmental control of the privately-owned major information agencies" 45 and emphasised their countries' "sovereign right of providing themselves with the most adequate [communication] instruments". ${ }^{46}$

Such statements aroused powerful opposition in Western oriented press quarters. The Inter American Press Association (IAPA), a Miami-based association of newspaper owners across the Americas, orchestrated public protest against what they saw as governmental attack on press freedom and the free market. ${ }^{47}$ At an “emergency meeting” held parallel to a UNESCO conference in 1976, they declared

42 Amadou-Mahtar M'Bow, Unesco and the Solidarity of Nations. The spirit of Nairobi, Paris 1977, UNESDOC.

43 First Symposium of Non-Aligned Countries on Information, b. Report of the First Committee, in: Jankowitsch/-Sauvant (eds.), Third World Without Superpowers, vol. VI.

44 M'Bow, Moving Towards Change, 91-92.

45 UNESCO, Review of the Texts Prepared to Date of A Draft Declaration on the Use of the Mass Media, Paris, June 1977, in: CRC: 1967-1989, Folder: 307 A 102 Declaration on the Use of the Mass Media, Part IV, UAP, 55.

46 Intergovernmental Conference on Communication Policies in Latin America and the Caribbean, San José (Costa Rica), 12-21 July 1976, Final Report, COM/MD/38, UNESDOC, 38.

47 Picasso to Zaher, 25.11.1975, AG 8, Series: DDG 2, Folder: 149 (DDG 2/46), UAP. 
that UNESCO's approach was not only "threatening to the free press of the Americas, but carries potential danger to the press of the entire world". ${ }^{48}$ The big news agencies took up the challenge, too. While representatives of Associated Press lobbied the US administration directly to defend their interests at UNESCO, Reuter's Gerald Long engaged in a debate with the so called "MacBride-Commission" for the Study of Communication Problems set up in $1977 .{ }^{49}$

On the cultural level, the Mass Media Declaration was expected to carry further the basic impetus of the earlier Satellite-Declaration, i.e. a regulation of the influx of media content from abroad. At an early expert meeting on the Mass Media Declaration, representatives from developing countries warned of the risk that their country's culture was being "submerged or dominated by foreign sources". The free-flow-principle would not work if "certain countries lacked the production capacity to participate" in it. This criticism targeted not only the technical disparities, but also the qualitative side of reporting. Media organisations from the industrialised North were felt not "to make even an attempt to understand the legitimate cultures and aspirations of certain countries". ${ }^{0}$ The Tunis Symposium consequently assigned the news media in non-aligned countries the task to affirm the "cultural personality" of these countries and support the struggle for emancipation and preservation of their identity where people found themselves under (neo-)colonial dominance. Exemplary reference was made to the Palestinians, the Rhodesians and the South Africans who were combating "Zionism, racism, neo-colonialism and fascism". 51

This content-oriented, qualitative criticism of the "free flow"-doctrine went beyond the economic and structural arguments. If an early draft of the Declaration included the "right of States and information media in each country to diffuse reports of national events to others beyond their border", such right was thought to address global imbalances in the representation of the Third World. ${ }^{52}$ The issue of representation, however, was much more difficult to address as it could not be

48 George Beebe, Remarks at the San José, Costa Rica Emergency Session of the IAPA Executive Committee - July 12, 1976, Box: 20, Folder: 24, World Press Freedom Committee Records, World Press Freedom Committee Records 1921-2009 [WPFCR], Department of Rare Books and Special Collections, Princeton University.

49 Michael Palmer, 'NWICO: Reuters' Gerald Long versus UNESCO’s Seán MacBride', in: Divina Frau-Meigs et al. (eds.), From NWICO to WSIS: 30 Years of Communication Geopolitics Actors and Flows, Structures and Divides, Bristol 2012, 41-54. For Reuters' strategy of partial accommodation see Brennan, 'Cold War Battle'.

50 UNESCO, Meeting of Experts on a Draft Declaration concerning the Rôle of the Mass Media, Paris, March 11-15, 1974, Report of the Meeting, UNESDOC, 2.

51 First Symposium of Non-Aligned Countries on Information, a Final Report.

52 UNESCO, Meeting of Experts on a Draft Declaration, 1974, Annex I, 2. 
mitigated through technical assistance, transmission rates or regional new exchanges. Western adherents to a free press tradition pointed to the ambivalence of such "cultural” arguments. A liberal journalist association warned that governments "could use the pretext of preserving their own national integrity to encroach on the necessary independence of the mass media profession, and suppress dissenting voices". ${ }^{53}$ Furthermore, there was a problem of defining what "national culture" could even be, given that in any state a lesser or stronger degree of pluralism and heterogeneity in the society made the assumption of a unifying cultural band rather artificial. A typical Western response was that the "diversity of sources of news and opinion" was the best guarantee of the free cultural development in any given country. ${ }^{54}$

Related to the issue of representation was an ultimately political argument, the third dimension of the claim to sovereignty in the communication field. In a moment of surprising harmony, socialist and Western negotiators proposed the inclusion of a paragraph praising the achievements of detente and of the Conference on Security and Co-operation in Europe in the Mass Media Declaration. Third World delegates wondered why a conference which related to only one world region would merit special mention. Instead, attention should be drawn "to the constructive contribution towards greater justice in international affairs made by conferences held by the countries of the Third World, and in particular by the non-aligned nations, in the context of efforts to establish a new world order". 55

At Tunis, non-aligned actors had accused the dominant foreign media of being hostile towards the political ambitions of the NIEO agenda. In the context of the Mass Media Declaration, they urged that an article be included stating "the mass media have a duty to make widely known among the peoples of the world the objectives of equity, sovereign equality, interdependence, common interest and co-operation among all States, on which [. . . ] the foundations of a new international economic order are based". 56 The underlying argument was that if the media could be tasked to celebrate détente it needed to be equally enlisted to promote non-aligned reform efforts for a more just international order. If not in such imperative modality, the final version of the Declaration did state that by disseminating the non-aligned initiatives and related UN decisions, mass

53 UNESCO, Meeting of Experts on a Draft Declaration, 1974, Annex I, 2.

54 Ibid.

55 See the report of an intergovernmental meeting in Paris in December 1975, in: UNESCO, Records of the General Conference, $19^{\text {th }}$ Session, Nairobi 1976, 19 C/91, Draft Declaration on Fundamental Principles Governing the Use of the Mass Media, 01.07.1976, Annex II, UNESDOC, 3.

5619 C/91, Annex I, 3. 
media would "contribute effectively [. . .] to the establishment of a more just and equitable international economic order". 57 The importance of public opinion in the process of bringing about a new order and the part the media could play in it thus emerged clearly from the Declaration.

\section{Inconclusive compromise}

On 23 November 1978, the New York Times printed the entire text of the Mass Media Declaration that had been adopted one day earlier in Paris at UNESCO's ongoing twentieth General Conference. ${ }^{58}$ This rare instance of a world leading newspaper printing a full declaration of a UN organ, couched in lofty, abstract language indicated the importance some media organisations accorded to the UNESCO debates. An editorial comment reflected on the nature of the outcome: "Western diplomats are congratulating themselves on having turned a dangerous international declaration on the obligations of the press into an incomprehensible hodgepodge of slogans and prescriptions."59 In fact, UNESCO’s Director-General himself declared that nobody "can expect to find in it, word by word, the exact draft he would like to. On the other hand, nobody can say that it runs counter, in any profound sense, to the principles to which he is deeply attached". ${ }^{0}$

Many of the issues raised by the non-aligned actors could somehow be read into the text but did not emerge directly from it. Reference to the NIEO was maintained, yet the role of the media in promoting it was not specified. The aspects of economic support and the state's role in the establishment of national media as well as of the developing countries' ability to project a different image abroad were mentioned implicitly. One article gestured towards the need for the international community to provide the necessary conditions and resources to developing countries without stating how. ${ }^{61}$ Notions of state control or of social and cultural responsibilities of the media were purged from the text.

But even though the final text was bland and abstract, the real meaning of the Mass Media Declaration derived from the amount of analysis it had produced and from its quality as a forum to discuss a broad set of ideas. It would go on to do so since the Declaration called UNESCO to further support the "aspiration

$5720 \mathrm{C} / 20 \mathrm{Rev}$.

58 Text of the UNESCO Compromise Declaration, New York Times, 23.11.1978, A12.

59 The Media and the Goats, New York Times, 27.11.1978, A18.

60 UNESCO, Records of the General Conference, $20^{\text {th }}$ Session, Paris 1978, 20 C/2 Reports, UNESDOC,153.

6120 C/ 20 Rev. 
of the developing countries for the establishment of a new, more just and more effective world information and communication order". 62

\section{Conclusion}

The debate on the NWICO thus continued. In 1977, UNESCO installed the "International Commission for the Study of Communication Problems”, also known as "MacBride-Commission" after its chairman, Seán MacBride. Public attention peaked in 1980 when the Commission presented its final report "Many Voices One World”. The political fallout of the decade long controversy troubled UNESCO well into the 1980s.

In the meantime, the arguments of the non-aligned in support of a new global media order had made yet another turn. The Tunisian member of the MacBrideCommission blamed the failure of the NIEO partly on the media in developed countries who had rendered public opinion "allergic to all claims and demands from the Third World". ${ }^{63}$ Mohammed Bedjaoui, an Algerian jurist and important intellectual in the NIEO movement, concluded "world public opinion must be educated" towards the achievement of greater economic justice, but "the path is virtually blocked by the five big news agencies”. The NIEO could only emerge if this situation changed. For this to change, a new economic order was required - “a vicious circle”. ${ }^{64}$ In 1980, member states at UNESCO's General Conference agreed that "the new international economic order necessarily presupposes a new world information and communication order based on a free flow and wider and better-balanced dissemination of information [emphasis added]". ${ }^{65}$ The NIEO-discourse was turned on its head. Even so, a declaration spelling out a New World Information and Communication Order never materialized.

One set of conclusions pertains to UNESCO's claim to sovereignty over culture: When UNESCO's leadership seized the NIEO-moment to promote a "socio-cultural dimension" in the global reform efforts, it defined culture's place in international relations. It did so through the lens of international communication and mass media. UNESCO did not define culture, media or information directly, but the NWICO debate produced important claims about the constitutive role of mass

62 Ibid., Preamble.

63 Masmoudi, New International Information Order, 2.

64 Mohammed Bedjaoui, Towards a New International Economic Order, Paris 1979, 120.

65 UNESCO, Records of the General Conference, $21^{\text {st }}$ Session, Belgrade 1980, 21 C/Resolutions, Resolution 9: New International Economic Order, UNESDOC, 102. 
media in development and international politics, the relevance of cultural relations for global power balances and the predominance of a Western perspective on global affairs. The NWICO-label sought to make culture an object of governance and opened a field for policy debate and operative measures. When UNESCO declared the 1970s the "communication decade", it hence performed an act of self-empowerment. As the responsible UN organ, it had to gain in visibility and resources from leading reform efforts in this field.

The language in which the NWICO-claims were articulated emphasised the nation state as main frame of understanding. This was natural since UNESCO was constituted as intergovernmental body. At the same time, for non-aligned countries confirmation of their statehood was a prime concern and they identified in the NWICO a set of instruments that could assist their fight against "neocolonialism" and for a new global order.

The congruence of UNESCO and non-aligned interests, however, should not be overstated. Precisely in the meaning of "cultural identity" important differences persisted. At UNESCO, it was imbedded in a humanistic universalism. This universalism granted that there was cultural pluralism - among nations, but also among peoples and within states. The tension between the strictly national frame and the inherent pluralism at UNESCO was never resolved, and certainly also within UNESCO different persuasions competed on this delicate interplay. ${ }^{66}$ To NWICO-critics, UNESCO had become a forum for an assertive nationalism of Third World governments. UNESCO's claim of sovereignty over culture ultimately undermined its credibility as an unbiased broker of international agreements.

Another set of conclusions addresses the intricacies involved for Third World countries in claiming "cultural sovereignty" at the international level. Staking out such claims at UNESCO was itself a performance of sovereignty. Not only was their statehood confirmed through the membership in the UN, their active participation proved their capacity to act on an equal footing within the international community. The rules of this game, though, were more complicated as they involved engaging in an uncontrollable public debate, compromising and a certain degree of public scrutiny.

The push-back against "cultural imperialism" was a legitimate concern even for many Western observers. Calls for control over information flows and national media sectors, in turn, were criticized as a maneuver of governments to protect their own positions in contested national politics. The case of the Indian Emergency in 1975-1977, in which Prime Minister Indira Gandhi limited the movement

66 See also Tomlinson, Cultural Imperialism, 71ff. 
of journalists and was accused of human rights violations and extrajudicial persecution of opposition members was one of many instances, when NWICO-critics pointed to the tensions between the international claims and national practices. ${ }^{67}$ None of the UNESCO declarations actually sanctioned government control. Instead, later efforts in democratising the media at the national and regional level partially drew on the legacy of the NWICO, as Vanessa Freije has shown in her study of Latin American Advocacy for a New International Information Order. ${ }^{68}$

Beyond such inherent contradictions, the NWICO campaign lost momentum also due to competing sovereignties at the horizontal level. The case of the NANAP and other regional news exchange schemes demonstrated that competition among developing countries complicated collaboration and limited their capacity to project a more positive image to publics around the world.

A third set of conclusions would have to take account of the multiplicity of parties involved in the NWICO-debate - this was treated only tacitly in this essay. One of the most important features of UNESCO as a forum was that despite its intergovernmental character it allowed for the interplay of many actors and interests, including state but also non-state actors like academics, business and the media itself. Together they produced a wealth of research, concepts and policy ideas. This inclusiveness contributed to the demise of the strongest calls for state control and limits to media flows. Somewhat ironically then, a final observation might suggest that UNESCO's claim to sovereignty over culture and the nonaligned countries claim to "cultural sovereignty" did not strengthen their positions but actually prepared a diffusion of sovereignty.

67 George Verghese, 'Press Censorship Under Indira Gandhi', in: Horton (ed.), The Third World, 220-230.

68 Freije, 'The "emancipation of media”, 